\title{
Recovery of Organic Acids from Fermentation Broth Using Nanofiltration Technologies: A Review
}

\author{
Nadiah Khairul Zaman, ${ }^{1}$ Jeng Yih Law, ${ }^{1,2}$ Pui Vun Chai, ${ }^{1}$ \\ ${\text { Rosiah Rohani }{ }^{* *} \text { and Abdul Wahab Mohammad }}^{1}$ \\ ${ }^{1}$ Department of Chemical and Process Engineering, \\ Faculty of Engineering and Built Environment, \\ Universiti Kebangsaan Malaysia, 43600 UKM Bangi, Selangor, Malaysia \\ ${ }^{2}$ Section of Chemical Engineering Technology, Universiti Kuala Lumpur, \\ Malaysian Institute of Chemical and Bioengineering Technology, \\ 78000 Alor Gajah, Melaka, Malaysia \\ "Corresponding author: rosiah@ukm.edu.my
}

Published online: 15 February 2017

To cite this article: Khairul Zaman, N. et al. (2017). Recovery of organic acids from fermentation broth using nanofiltration technologies: A review. J. Phys. Sci., 28(Supp. 1), 85-109, https://doi.org/10.21315/jps2017.28.s1.6

To link to this article: https://doi.org/10.21315/jps2017.28.s1.6

\begin{abstract}
Organic acids are important targeted chemicals in the renewable biorefinery industry. They are widely used in various industries due to their variety of functionalities and less toxic properties. Conventionally, organic acids are produced through chemical processing using fossil raw materials. However, the biological production pathway has gained significant attention in recent years due to the growing environmental concern and movement towards green technology. To date, a variety of high-value organic acids such as succinic, lactic, butyric, acetic and fumaric acids have been produced via microbial fermentation. The primary challenge in the fermentative production of organic acids is the downstream recovery of the main products from the broth solution. Integration of membrane technology with other separation technologies in the downstream processing is deemed as a great opportunity for this purpose, for which membrane-based nanofiltration is seen as the potential technology. Nanofiltration offers several advantages such as great flexibility in the scale of production, high degree of separation and selectivity, and can be easily integrated with other separation units. This paper reviews the recovery of organic acids from fermentation broth using nanofiltration technologies, of which five types of organic acids are discussed in-depth. In particular, valuable findings concerning the effect of membrane properties, type of membrane used, and the effect of processing parameters on the organic acids recovery are highlighted in this paper.
\end{abstract}

Keywords: Organic acids, fermentation, nanofiltration, membrane, biomass 


\section{INTRODUCTION}

From the preindustrial era until present, there has been a great interest in renewable raw materials, from coal in the 19th century to cheaper crude oil and natural gas in the 20th century, and recently a great interest has shifted towards biomass. ${ }^{1}$ The present shifting in trend towards biomass as an alternative source to replace petrochemical feedstock specifically from non-renewable source is driven by the current needs to reduce pollution resulting from petrochemical processing. ${ }^{2}$ As biorefinery utilises renewable resources as feedstocks, it can reduce the carbon footprint for sustainable development.

Biomass can be defined as the organic matter which is constantly available on renewable basis in the form of solid and liquid from crops, agricultural, forestry residues, waste and existing forestry. It mainly consists of starch, cellulose, hemicellulose, lignin, oil and protein, in which every part can be converted into high value chemicals via biological process. ${ }^{1}$ Unlike the traditional chemical industry that directly utilises crude oil (hydrocarbons) as raw materials for the production of organic chemicals, biochemical industry involves biomass conversion to chemical products via fermentation. ${ }^{1}$

To date, a variety of high-value organic acids such as succinic, lactic, butyric, acetic and fumaric acids have been produced via microbial fermentation. These organic acids are of high interest, mainly as precursors for synthesising a variety of valuable chemical derivatives via different chemical conversion pathways. The applications of these organic acids are gathered and presented in Table 1. However, there are several key challenges in the biological production of organic acids including: the relatively low product concentration in the broth; difficult product recovery that requires specific separation technologies; the production of acids in salt form; and the formation of by-products. ${ }^{3}$ Although biomass as a source of feedstock is of increasing importance, in-depth analysis and understanding are needed to develop economically competitive and environmentally sound alternative routes.

Various methods have been reported on the separation and recovery of high value acids from biomass fermentation which include reactive extraction with amine-based extractant, ${ }^{2}$ direct crystallisation, ${ }^{4}$ membrane separation, ${ }^{5,6}$ and electrodialysis. ${ }^{7}$ Nevertheless, the existing recovery processes still suffer from low selectivity of targeted acid. ${ }^{4}$ This is due to the similarity in properties and behaviours of the main product and the by-products of carboxylic acids in the acid mixture at room temperature. ${ }^{8}$ 
Inrecentyears, membrane-based technology has gained importancein biotechnology industry especially NF due to its unique separation principle of selective transport based on the molecular sieve effect and/or on charge effect depending on the type of membrane used and the feed properties. NF could efficiently separate monovalent salt and small organics from divalent ions and larger species by manipulating the properties of the membrane utilised such as surface zeta potential. ${ }^{9}$ Previous study reported that membrane with more negative surface zeta potential separates the organic acid salts better than membrane with low surface zeta potential. ${ }^{6,10}$

This paper reviews the recovery of organic acids from fermentation broth using NF technologies, of which five types of organic acids are discussed in-depth. The review begins with a fundamental introduction to membrane-based separation, which includes the superiority of NF membrane compared to other types of membranes in organic acid separation and NF separation principles, and mechanisms that enhance the properties of NF membranes in removal of multivalent ionic species compared to other membranes. Valuable findings concerning the effect of membrane properties, type of membrane used, and the effect of processing parameters on the organic acids recovery are also highlighted in this paper.

Table 1: Organic acids application.

\begin{tabular}{|c|c|}
\hline Organic Acids & Applications \\
\hline Succinic acid & $\begin{array}{l}\text { - Flavouring enhancer for beverages, catalyst for food seasoning } \\
\text { preparation and bread softening agent. }{ }^{11} \\
\text { - Anticarcinogenic and insulinotropic agents. }{ }^{12} \\
\text { - Precursor in the production of many important chemicals such as } \\
\text { tetrahydrofuran (THF), 1,4-butanediol (BDO), gamma-butyrolactone } \\
\text { (GBL), ethylenediamine disuccinate (a biodegradable chelator), } \\
\text { 1,4-butanediol (a plastic precursor) and adipic acid (nylon precursor) }{ }^{13}\end{array}$ \\
\hline Lactic acid & $\begin{array}{l}\text { - Ingredients in the production of many pharmaceuticals, cosmetics, } \\
\text { textiles and biodegradable polylactide. }{ }^{14}\end{array}$ \\
\hline Butyric acid & $\begin{array}{l}\text { - Textile fibres from cellulose acetate butyrate. }{ }^{15} \\
\text { - Biofuel production. }{ }^{16,17} \\
\text { - Applications in the food, chemical and pharmaceutical industries. } .^{15,16,18,19}\end{array}$ \\
\hline Acetic acid & $\begin{array}{l}\text { - Raw material for vinyl acetate monomer (VAM) and acetic anhydride } \\
\text { synthesis. }{ }^{20} \\
\text { - As a solvent for purified terephthalic acid (PTA) production. }{ }^{20}\end{array}$ \\
\hline
\end{tabular}




\section{MEMBRANE BASED SEPARATION}

For the past two decades, membrane-based separation process has been developed for specific used in biotechnology industries, which utilises different ranges of pressure-driven filtration membranes including microfiltration (MF), ultrafiltration (UF) and nanofiltration (NF). These membranes are responsible in the separation of different components from various bioprocesses including proteins, amino acids, sugars, vitamins and organic acids. MF being the most established process compared to UF and NF, has already been used in separation areas such as environmental engineering, biotechnology, life sciences and medicine. ${ }^{21}$ It separates fine particles in the size range of $0.1-10.0 \mu \mathrm{m}$, which usually involves retaining cells and cell debris while allowing proteins and smaller macromolecules to pass through it. For smaller compounds such as protein and macromolecules, UF membranes with pore size range of $1-100 \mathrm{~nm}$ suited well. ${ }^{22}$ In addition to the separation of downstream products of biotechnology industry, UF membranes have also been used to concentrate whey proteins during the production of dairy products.

Meanwhile, NF membrane is responsible in separating and recovering much smaller compounds such as solvent, salt, microorganism (bacteria and viruses) and dissolved organic compounds due its smaller membrane pore size of around 0.5 to $1 \mathrm{~nm}$. NF separation is based on sieving and charge effects due to the presence of ionisable groups on the surface of the membrane, ${ }^{23}$ thus the properties of the NF membrane could be exploited either through membrane modification and/or by selecting the best membrane material in order to enhance selective separation of the multivalent ionic species in the feed solution. Table 2 presents the overview of different membrane types and their characteristics.

\subsection{NF Separation Principle and Mechanisms}

Generally, rejection mechanisms of NF can be divided into two types, which are sieving and non-sieving rejection mechanisms. The mechanisms are applicable for all NF membranes regardless of the type of polymer used to fabricate the membranes. Sieving mechanism is relatively simple and well established, where separations of neutral solutes through the NF membrane are dependent on the pore size of the membrane. Non-sieving mechanisms, on the other hand are more complex and can be singled out into Donnan exclusion, dielectric exclusion and "hydration mechanism." ${ }^{23,25}$ It is believed that every NF membranes may have different dominant rejection mechanism for combinations of several rejection mechanisms, depending on the micro-hydrodynamic and interfacial events occurring at the membrane surface and within the membrane nanopores..$^{23,26}$ 
Table 2: The overview of different membrane types and their characteristics.

\begin{tabular}{lccc}
\hline & Microfiltration (MF) & Ultrafiltration (UF) & Nanofiltration (NF) \\
\hline Permeability (LMH/bar) & $>1000$ & $10-1000$ & $1.5-30$ \\
Pressure (bar) & $0.1-2$ & $0.1-5$ & $3-20$ \\
Pore size (nm) & $100-10000$ & $2-100$ & $0.5-2$ \\
Rejection & & & \\
Particles & $\mathbf{x}$ & $\checkmark$ & $\checkmark$ \\
Macromolecules & $\mathbf{x}$ & $\mathbf{x}$ & $\checkmark$ \\
Small organic & $\mathbf{x}$ & $\checkmark$ or $\mathbf{x}$ & $\checkmark$ or $\mathbf{r}$ \\
Multivalent ions & Sieving & Sieving & $\mathbf{x}$ \\
Monovalent ions & & & Sieving \\
Separation mechanism & & & Charge effects \\
\hline
\end{tabular}

Source: Oatley et al. $(2012)^{26}$

Donnan exclusion is a classical known rejection mechanism in NF separation, which is usually used to describe the high rejection of divalent ions and low rejection of monovalent ions in organic acids separation. ${ }^{6,10}$ It describes the membrane potential interaction between charge species and the fixed electrical charges attached to the membrane matrix. ${ }^{27}$ The charge of NF membrane was reported to originate from the dissociation of surface groups such as sulfonated or carboxyl acids and from within the membrane pore structure. ${ }^{28,29}$ The membrane surface groups can either be acidic, basic or a combination of both, depending on the specific materials used during the membrane fabrication process. ${ }^{23}$ Discussions on acidic surface charge of NF membranes could be found in open literatures as these membranes are reportedly used for acids separation/recovery especially from organic sources.

Table 3 presents different commercial NF membranes available that have been tested for organic acids separation with specification from the manufacturers..$^{23,30}$ Upon contacting the membranes with ionic solution, membrane surface charge would form an electrostatic interaction with the ions in solution and may exhibit an isoelectric point at a specific $\mathrm{pH}$ due to amphoteric nature of the membrane surface chemistry. The dissociation of the membrane surface groups is strongly influenced by the condition of the contacting solutions namely $\mathrm{pH}$ and concentration. ${ }^{29} \mathrm{This}$ special electrostatic interaction is the reason for the better selectivity of divalent ions from the monovalent ions possessed by NF membranes. 
Table 3: Commercial polymeric NF membranes utilised for organic acid separation and their specification from the manufacturers.

\begin{tabular}{|c|c|c|c|c|c|}
\hline Membrane & Manufacturer & $\begin{array}{l}\text { MWCO } \\
\text { (Da) }\end{array}$ & $\mathrm{pH}$ range & $\begin{array}{l}\text { Stabilised salt } \\
\text { rejection (\%) }\end{array}$ & $\begin{array}{c}\text { Composition of } \\
\text { top layer }\end{array}$ \\
\hline NF45 & Dow Filmtech $^{\mathrm{a}}$ & 300 & $3-10$ & $>98 \% \mathrm{MgSO}_{4}$ & Polypiperazine-amide \\
\hline NF70 & Dow Filmtech ${ }^{\mathrm{a}}$ & $200-300$ & $3-9$ & $>95 \% \mathrm{MgSO}_{4}$ & $\begin{array}{l}\text { Aromatic crosslinked } \\
\text { polyamide }\end{array}$ \\
\hline NF90 & Dow Filmtech ${ }^{\mathrm{a}}$ & $200-400$ & $3-10$ & $\begin{array}{c}85 \%-95 \% \mathrm{NaCl} \\
>97 \% \mathrm{CaCl}_{2}\end{array}$ & $\begin{array}{l}\text { Polyamide thin-film } \\
\text { composite }\end{array}$ \\
\hline NF270 & Dow Filmtech ${ }^{\mathrm{a}}$ & $200-400$ & $2-11$ & $>97 \%$ & $\begin{array}{l}\text { Polyamide thin-film } \\
\text { composite }\end{array}$ \\
\hline NTR-729HF & Hydranautics ${ }^{\mathrm{b}}$ & 700 & $2-12$ & $70 \% \mathrm{NaCl}$ & $\begin{array}{l}\text { Poly(vinyl)alcohol/ } \\
\text { polyamide }\end{array}$ \\
\hline ESNA1 & Hydranautics $^{\mathrm{b}}$ & $100-300$ & $2-10$ & $89 \%$ & Composite polyamide \\
\hline TS-4040 & Trisep $^{c}$ & 200 & $3-10$ & $99 \%$ & Polypiperazine-amide \\
\hline DK & GE Osmonics $^{\mathrm{d}}$ & 200 & $3-9$ & $98 \% \mathrm{MgSO}_{4}$ & Polyamide \\
\hline DL & GE Osmonics $^{\mathrm{d}}$ & $150-300$ & $1-11$ & $96 \% \mathrm{MgSO}_{4}$ & $\begin{array}{c}\text { Cross-linked aromatic } \\
\text { polyamide }\end{array}$ \\
\hline NP010 & Microdyn Nadir & - & $1-14$ & $\begin{array}{c}25 \%-40 \% \\
\mathrm{Na}_{2} \mathrm{SO}_{4}\end{array}$ & Polyethersulfone \\
\hline NP030 & Microdyn Nadir & - & $1-14$ & $\begin{array}{c}80 \%-95 \% \\
\mathrm{Na}_{2} \mathrm{SO}_{4}\end{array}$ & Polyethersulfone \\
\hline ES10 & Nitto Denko ${ }^{\mathrm{f}}$ & 100 & - & $99.5 \%$ & Aromatic polyamide \\
\hline DK25040 & $\begin{array}{c}\text { Filtration } \\
\text { Engineering }\end{array}$ & $300 / 0.92 *$ & $2.3-11$ & $30 \% \mathrm{CaCl}_{2}$ & Polyamide \\
\hline $\mathrm{AFC} 80$ & $\begin{array}{l}\text { PCI Membrane } \\
\text { System }\end{array}$ & $0.68 *$ & $1.5-10.5$ & $80 \% \mathrm{NaCl}$ & Polyamide \\
\hline
\end{tabular}

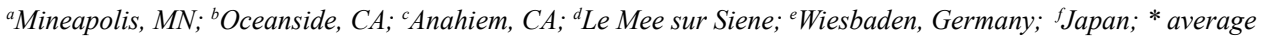
pore size $(\mathrm{nm})$

Unlike Donnan exclusion mechanism, dielectric exclusion and "hydration mechanism" were not really well understood. Nevertheless, previous studies have reported that the phenomenon of dielectric exclusion is due to the slight modification of membrane charge from the adsorbed ion of the contacting solution. ${ }^{25,31}$ This phenomenon described that the ion valence and fixed charge of membrane vary depending on the contacting solution, which controls the electrostatic repulsion or attraction of a NF membrane. ${ }^{23}$

Yaroshchuk ${ }^{25}$ had also described that the dielectric exclusion/partitioning can arise when an ion interacts with the bound electrical charges, which is induced by the ion at the interface between materials of different dielectric constant (which in this case 
membrane matrix and the solvent). Subsequently, the ion polarises the two media according to their relative dielectric constant and a distribution of polarisation charge builds at the discontinuity surface. The dielectric exclusion mechanism is usually used to describe the rejection mechanism of non-symmetrical electrolyte mixture containing ions of different charges. The detail interactions has been reviewed by Oatley et al. ${ }^{26}$ Meanwhile, for hydration mechanism, only limited description was reported. Yaroshchuk ${ }^{25}$ has described the rejection performance of NF membrane based on hydration mechanism from the loss of water dissolving ability of the NF membrane. Nevertheless, it was reported that the hydration mechanism was closely related to the changes in the membrane dielectric properties. ${ }^{25}$

\section{NF MEMBRANE RECOVERY FOR ORGANIC ACIDS}

\subsection{Succinic Acid}

Kang and Chang ${ }^{6}$ investigated the recovery of sodium succinate (the conjugated based of succinic acid) and removal of by-products such as sodium acetate, formate and lactate from simulated fermentation broth using different types of commercial membranes. According to their study, ${ }^{8} \mathrm{NF} 45$ and ESNA1 membranes demonstrated good separation performance of divalent from monovalent anions evaluated based on the rejections of salts. NF45 membrane demonstrated salt rejection sequence of $\mathrm{MgSO}_{4} \approx \mathrm{Na}_{2} \mathrm{SO}_{4}>\mathrm{MgCl}_{2}>\mathrm{NaCl}$, while ESNA1 membrane demonstrated salt rejection sequence of $\mathrm{Na}_{2} \mathrm{SO}_{4}>\mathrm{NaCl} \approx \mathrm{MgSO}_{4}>\mathrm{MgCl}_{2}$.

The difference in salt rejection sequence, in which ESNA1 exhibited higher rejection of $\mathrm{Cl}^{-}$compared to NF45 indicated that ESNA1 had more negative surface charge. ESNA1 membrane was also found to have larger pore size compared to NF45, which is $52.8 \%$ compared to $85.9 \%$ rejection of PEG200, respectively. Therefore it was concluded that the separation mechanism of ESNA1 was dominated by Donnan exclusion, while, NF45 membrane was dominated by Donnan exclusion and sieve effects as the major factors contributing to the separation of ions. ${ }^{32}$ Even though both membranes were fabricated from polyamide as presented in Table 3 , different polyamide composition presence in the membrane top layers produces membrane with different properties, which has significant effects on the rejection mechanisms, hence affecting the rejection performance of the membrane.

The rejection performance of NF45 and ESNA1 membranes were also further investigated using single, binary, ternary and quaternary organic salt solutions containing sodium succinate, lactate, formate and acetate. It was reported that succinate (divalent anion) showed higher rejection while lactate, formate and acetate 
(monovalent anions) showed the opposite trend when mixture solutions were used and selectivity of succinate also increased with the increase in concentration ratio of divalent to monovalent anions. ${ }^{33}$ This is believed to be due to the presence of interaction between both anions, known as pumping effect.

In the presence of divalent anion, a strong repulsion of divalent anion from the membrane surface pushes the monovalent anion towards the membrane surface to meet the electro-neutrality in the membrane phase. Therefore, this increases the monovalent concentration in the membrane phase, which resulted in more monovalent anions to easily pass through the membrane. In comparing the rejection of sodium succinate, ESNA1 showed much lower rejection compared to NF45 but for rejection of monovalent anions, ESNA1 has higher rejection. The former observation is due to the larger MWCO of ESNA1 membrane, while the latter may be due to ESNA1 membrane having higher surface charge compared to NF45 membrane.

The high surface charge of ESNA1 membrane indicates that the membrane would have low ratio of monovalent concentration at the membrane phase compared to the bulk concentration (known as distribution coefficient) due to the presence of strong repulsion effects from the membrane. ${ }^{32}$ This consequently resulted in higher rejection of monovalent anions as the permeation of the anions become less feasible. As NF45 show better performance than ESNA1, NF45 was tested for the recovery of succinate via diafiltration mode for $36 \mathrm{~h}$ using quaternary acid salts solution. With time, the recovery of succinate found to increase whereas the rejection of by-products (lactate, formate and acetate) decreased. The final succinate rejection obtained was $78.2 \%$ while the rejection of formate, acetate and lactate were $-97.6 \%,-54.6 \%$ and $-18.3 \%$, respectively.

Choi et al. ${ }^{10}$ performed a study on the removal of organic acids from wastewater, which focuses on the rejection of organic acids at different operating parameters such as $\mathrm{pH}$, pressure and concentrations for five different organic acids (formic, acetic, propionic, succinic and citric acids) using ES10 and NF270 membranes. The significant difference in the properties of these membranes is the MWCO, where ES10 has much smaller MWCO of 100 Da while NF270 has larger MWCO of 200-300 Da. Other properties of membranes are presented in Table 3. Even though wastewater was highlighted as the feed solution, the results reported in this study were noteworthy. In the separation of organic acid, it was found that the separation were also influenced by the molecular weight (MW) of the organic acid, either it is larger than/close to the MWCO of the membrane or it is much smaller than the MWCO of the membrane. 
For organic acid with MW larger than or close to the MWCO of membrane, the rejection was driven more by sieving than electrostatic repulsion, and hence, the effect of $\mathrm{pH}$ on the rejection was not significant. This was evident by the high rejection (>90\%) of succinic acid (MW: 118.09 Da) and citric acid (MW: 192.13 $\mathrm{Da}$ ) regardless of $\mathrm{pH}$ studied observed for ES10 membrane. From the results obtained, it can be seen that the rejection performance of ES10 is dominated by the sieving effect. ${ }^{25,34}$ This is due to the much smaller MWCO of membrane compared to MW of the organic acids investigated, which hindered the permeation of large organic acids to pass to the membrane, thus resulting in high rejection of succinic and citric acid. However, for small MW of organic acid such as formic acid, the rejection behaviour is affected by the variation in $\mathrm{pH}$. The rejection of formic acid was obtained in a range of $2 \%$ to $96 \%$ over $\mathrm{pH}$ variation, which implied that separation mechanism of formic acid may be also driven by the electrostatic repulsion (known as Donnan exclusion) besides the sieving effect. ${ }^{6,27}$

Similar results as in rejection of formic acid using ES10 membrane was observed for NF270. Having much larger MWCO compared to the MW of organic acids investigated, the rejection performance of NF270 was strongly influenced by $\mathrm{pH}$ variation; the rejection of all organic acids increased with increasing $\mathrm{pH}$. This is attributed to the increase in membrane surface charge with increasing $\mathrm{pH}$. Hence, it resulted in an increase in electrostatic repulsion between solute and membrane, thus increasing the rejection of organic acids. ${ }^{10}$ NF270 membrane also exhibited higher membrane surface charge compared to ES10 membrane, as indicated from the surface zeta potential analysis. ES10 shows an isoelectric point (IEP) close to $\mathrm{pH} 3$ but NF270 did not show any IEP within the $\mathrm{pH}$ range of 2-10. Moreover, for the influence of pressure on the rejection of organic acids, the results follow the trend as in $\mathrm{pH}$ variation. Large $\mathrm{MW}$ compound such as succinic and citric acids showed high rejections of over $90 \%$ irrespective of the operating pressure. However, for organic acids with much smaller MW compared to the employed NF membranes, the rejection increased gradually with increasing operating pressure, which is attributed to the increased in solvent flux. ${ }^{10}$

The study by Choi et al. ${ }^{10}$ also revealed that the concentration variation in between 50 and $500 \mathrm{mg} / \mathrm{L}$ had not much effect on the rejection performance of both membranes studied except for formic acid due to its small MW. Both ES10 and NF270 showed a reduction in rejection of formic acid at increasing concentration, with more pronounced reduction observed on NF270 membrane. The phenomenon can be explained with the charge shielding effect occurred on the membrane surface due to increasing feed concentration (i.e., ionic strength). ${ }^{35,36}$ At increasing feed concentration, the increasing counter-ions $\left(\mathrm{Na}^{+}\right)$in the solution could effectively screen the initially negative membrane surface charge, therefore 
neutralising the negative charge of the membrane and reduces the electrostatic effect of the membrane ${ }^{37}$ As a result, lower rejection of formic acid was obtained at higher feed concentration.

The more pronounced reduction observed for NF270 is due to its more negatively charged surface compared to ES10 indicated from the surface zeta potential analysis as discussed in previous paragraph. This phenomenon is closely related to the dielectric exclusion mechanism ${ }^{25}$ described in section 2.1. Overall, it could be seen that, separation performance of the membrane with MWCO much smaller than MW of the organic acids investigated was not affected much by the changes in the processing parameters such as $\mathrm{pH}$, pressure and concentration and vice versa. This phenomenon is due to the difference of separation mechanisms that had taken place when membranes with different properties were used.

Sosa et al. ${ }^{30}$ had proposed a novel integrated three-step, membrane-based succinic acid recovery system. Three different membrane-based processes which are electrodialysis (ED), NF and Donnan dialysis (DD) were employed in this study. However, the succinate recovery performance using NF membrane is the main interest since the same membrane filtration is reviewed in our work. Sosa et al. ${ }^{30}$ have operated NF in a diafiltration mode, which involved repeated refilling of the dead-end cell with distilled water replacing the volume of feed loss as permeate. The performance of six different NF membranes namely NF90, NF DK, NP030, NF270, NF DL and NP010 have been investigated and compared for the rejection and flux of mixture solution containing succinate (product), formate and acetate (by-products).

The properties of membranes and operating conditions are presented in Table 3 and 4, respectively. The results had demonstrated NF270, NF-DK and NF-DL as promising membranes due to their low rejections for acetate and formate while maintaining high succinate rejection and the membranes also presented reasonable permeate flux performance of $30 \mathrm{~L} / \mathrm{m}^{2} . h, 25 \mathrm{~L} / \mathrm{m}^{2} . h$ and $30 \mathrm{~L} / \mathrm{m}^{2} . h$, respectively. Nevertheless, NF270 showed slightly better results with the highest succinate rejection of $88.9 \%$, while formate and almost $90 \%$ of acetate were removed. Meanwhile, NF-DL membrane showed the highest effective removal of acetate with $94.9 \%$, but higher loss in succinate was observed. When tested with simulated carob pot extract fermentation broth, all membranes demonstrated higher succinate rejections of above $90 \%$ but lower removal degree of formate and acetate were observed compared to the results when model solutions were used. This difference was attributed to the distinct interactions of the compounds present with the membrane, but exact explanation was not given and required further dedicated 
studies. Nevertheless, it could be seen that the separation of organic acids could be further improved regardless of the type of membrane used when using diafiltration mode filtration compared to previous studies that utilised single dead end mode. ${ }^{6,10}$ With diafiltration, the repeated refilling of the dead end cell with pure water could further increase the recovery of succinate and remove the by-products of acetate and formate.

Unlike other literatures which reported the use of polymeric membranes in their studies, Staszak et al. ${ }^{38}$ employed ceramic membrane instead. They investigated the separation of organic acids including succinic and fumaric acids, in the presence of glycerol. Both organic acids showed slight reduction of retention in the presence of glycerol. Nevertheless, at increasing solution $\mathrm{pH}$, nearly all glycerol was successfully permeated through the membrane while organic acids in the form of salts were retained. NF ceramic membrane was found to be able to concentrate organic acid salts at low initial feed concentrations and at $\mathrm{pH}$ above the acid dissociation constants. Nevertheless, the separation trend of ceramic membrane was seen to be more or less the same as polymeric membrane. Staszak et al. ${ }^{38}$ also reported increment in rejection performance of organic acids at increasing $\mathrm{pH}$ and reduction in rejection at increasing feed concentration.

\subsection{Lactic Acid}

Lactic acid recovery from fermentation broth using NF membrane has been intensively reported. Gonzalez et al. ${ }^{39}$ reported the purification of lactic acid from clarified fermentation broths by NF spiral wound and tubular membrane modules. They investigated the effect of feed concentration, flow rate, transmembrane pressure and $\mathrm{pH}$ on flux and rejection and correlated the separation efficiency of the NF membranes with combination of size and charge effects. From the results, the electrostatic effect was found as the limiting factor in the recovery of lactic acids by means of NF. In acidic condition, the rejection of lactic acid and inorganic salts in the fermentation broth were low around $35 \%-58 \%$ and $45 \%-76 \%$, respectively. However, the lactic acid rejection increased with both $\mathrm{pH}$ and pressure but the flux reduced with increasing $\mathrm{pH}$. The lactate rejection of DK2540C membrane was $10 \%-91 \%$ in the $\mathrm{pH}$ range of $2.7-6$, whereas lactate rejection of AFC 80 membrane was $45 \%-82 \%$. Meanwhile, the feed flow rate, which influences the concentration polarisation, has not much effect on the performance of the membrane. From the results, it was observed that the degree of membrane surface charge influenced the retention of lactate. Although DK2540C membrane has a higher MWCO than the AFC80 membrane, lactate rejection was higher for the former membrane at high $\mathrm{pH}$ values. This is possibly due to the higher charge density possessed by 
DK2540C compared to AFC80 membrane. Similar results were also reported in a previous study.$^{10}$ However, at high feed concentration, solute retention was lower as the Donnan exclusion effect was attenuated. ${ }^{39}$

An integration of properly selected NF membrane with a fermenter can yield high purity of lactic acid through recovery and recycling routes. Bouchoux et al. ${ }^{40}$ investigated an integrated system of cross flow mode flat sheet NF membrane with a fermenter for the production and purification of lactic acid from glucose as presented in Figure 1. They performed the separation of glucose and lactic acid from single-solute solutions of sodium lactate and glucose and mixed-solute solutions containing both solutes using Desal $5 \mathrm{DK}$ membrane. The result indicated that the glucose retention decreased in the presence of sodium lactate, and that the decrement becomes more significant when higher concentration of charged solutes was present. As a result, the separation of sodium lactate from glucose was unachievable. The possible explanations could be due to two reasons: (1) an increase of membrane pore radius from the increase in membrane charge density in the presence of sodium lactate; and (2) a decrease of glucose hydrodynamic radius from the "salting-out" effect or a combination of the two phenomena. The decrease of neutral solute retention in the presence of charged solute is probably a general problem in the NF process of complex fluids.

Similar work has been done by Sikder et al. ${ }^{41}$ using cross-flow NF for recovering lactic acid from microfiltrate fermentation broth. The integration of NF membrane with a cell-recycle fermentation unit and lactate conversion unit could yield lactic acid with an optical purity of $85.6 \%$. The effects of cross flow rate, transmembrane pressure and $\mathrm{pH}$ on flux and rejection of acid and unconverted sugars were also analysed. The optimum conditions retaining $94 \%$ uncoverted sugars while rejecting $32 \%$ lactic acid with permeate flux of $113 \mathrm{~L} / \mathrm{m}^{2}$.h were obtained at $\mathrm{pH} 5.5$, temperature of $37^{\circ} \mathrm{C}$, transmembrane pressure of 13 bar and cross-flow velocity of $2.48 \mathrm{~m} / \mathrm{s}$. NF3 was found to be the best membrane compared to other two investigated membranes of NF2 and NF270. They also reported that the multiple purification steps could be replaced by combining NF with bipolar electrodialysis in the downstream purification.

Duke et al. ${ }^{44}$ investigated the effectiveness of mechanically strong inorganic membranes. They compared two readily available membranes including $\gamma$-alumina $\mathrm{NF}$ membrane and the more advanced molecular sieve silica membranes to enrich lactic acid product by selectively depleting water through the membrane. Selectivity factor (SF) of water over lactic acid and flux were used to evaluate the performance of membrane. SF $>1$ indicates that the permeate was enriched with water. From the results, silica membrane exhibited better performance with a 

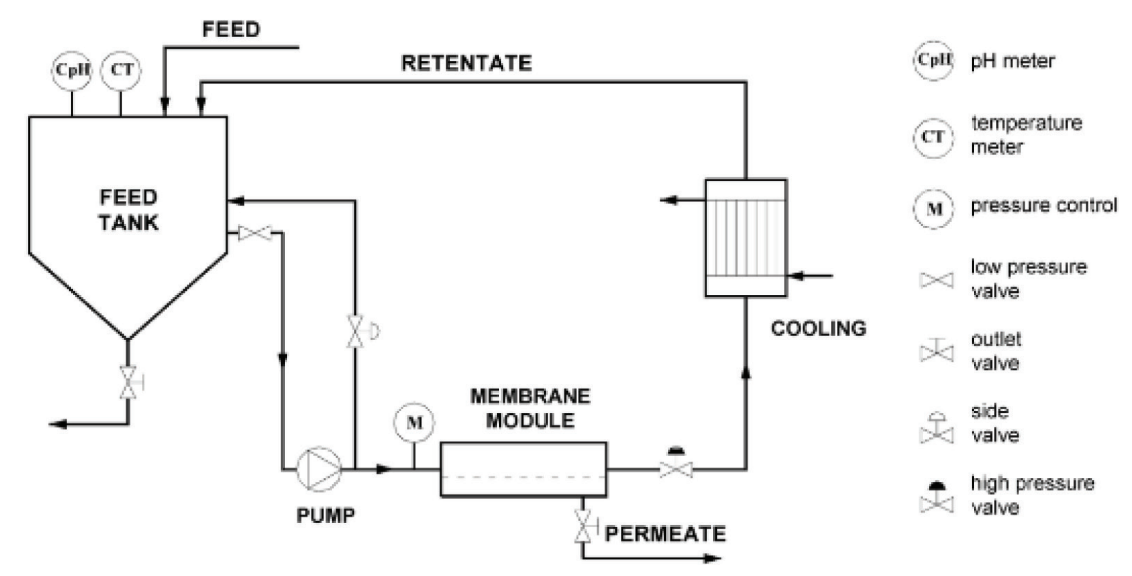

Figure 1: Cross-flow NF module coupled with fermenter for lactic acid recovery. ${ }^{40,42,43}$

water SF of up to 220 (rejection coefficient of 0.995 ) which is very high and low lactic acid amount of only $0.08 \mathrm{wt} \%$ in the permeate. Meanwhile, the alumina membrane only exhibited water SF of 9, with permeate lactic acid of $2 \mathrm{wt} \%$. The initial concentration of feed was $15 \mathrm{wt} \%$. A significant flux decrease from 6 to $1 \mathrm{~kg} / \mathrm{m}^{2}$ only after $250 \mathrm{~min}$ operation time of alumina membrane was observed explaining the low water SF obtained. It is believed to be due to pore blocking of lactic acid. Meanwhile silica membrane showed relatively stable flux of $0.2 \mathrm{~kg} / \mathrm{m}^{2} \mathrm{~h}$. Better performance of silica membrane compared to $\gamma$-alumina membrane was due to alumina's strong surface charge and wider pore size thus enabling a slow pore blocking mechanism resulting in flux dropping. Simultaneously, silica membrane exhibited tight pore spaces that inhibited lactic acid from entering and the charge-neutral surface leading to a more stable separation. Nevertheless, further development towards flux enhancement of such membranes is still required for commercial application.

\subsection{Butyric Acid}

One of the major concerns of the fermentation production of butyric acid is the downstream processing. Cho et al. ${ }^{17}$ proposed multistage integrated (UF/MF)NF-FO system configuration for the separation and recovery of organic acids from biomass fermentation in which the second and the third stages are the main focus of the recovery process (Figure 2). In the first stage, microorganisms and other large insoluble particles in fermentation broth are removed using MF or UF, also known as the pre-treatment stage. The second stage involved organic acid separation using crossflow NF and RO membranes. The NF membranes (HL, Duraslick) and RO membranes (XLE, LE) were supplied by GE and Dow Filmtec, 
respectively. Various operating conditions were used to investigate the effect of pressure and $\mathrm{pH}$ on the rejection performances of several solutes which include ammonium sulfate, potassium phosphate, glucose, yeast extract, and butyric acid (Table 4). The recovery of butyric acid was achieved by allowing the acid to pass through the membrane and collected as the permeate while retaining other solutes in the retentate stream. It was reported that the RO membranes exhibited much higher solute rejections including butyric acid than the NF membranes due to the highly dense active layers. In other words, lower recovery of butyric acid was observed for RO membranes. The effect of operating pressure indicated that the rejection ratios of all solutes increased with increasing applied feed pressure and that the highest rejection ratios were obtained at 15 bar. The rejections of inorganic solutes and butyric acid were also influenced by the variation of $\mathrm{pH}$ due to the electrostatic repulsion phenomenon. Butyric acid is a weak acid with $\mathrm{p} K_{\mathrm{a}}$ of 4.82. As anticipated, high permeation of butyric acid was obtained at lower $\mathrm{pH}$ due to the low hindrance effect of NF membranes. It was thus concluded that NF membranes demonstrated greater recovery of targeted butyric acid particularly at low $\mathrm{pH}$ condition compared to the $\mathrm{RO}$ membranes. ${ }^{17}$

In the final stage, forward osmosis (FO) was integrated as the dewatering process to concentrate the butyric acid solution. Commercial polyamide TFC membrane (XLE RO) and CTA FO membrane (Hydration Technology Innovations (HTI), Albany, OR, USA) were employed in the study. CTA FO membrane exhibited greater water flux across the membrane, which is 3 to 4 times higher than the XLE RO membrane. ${ }^{17}$

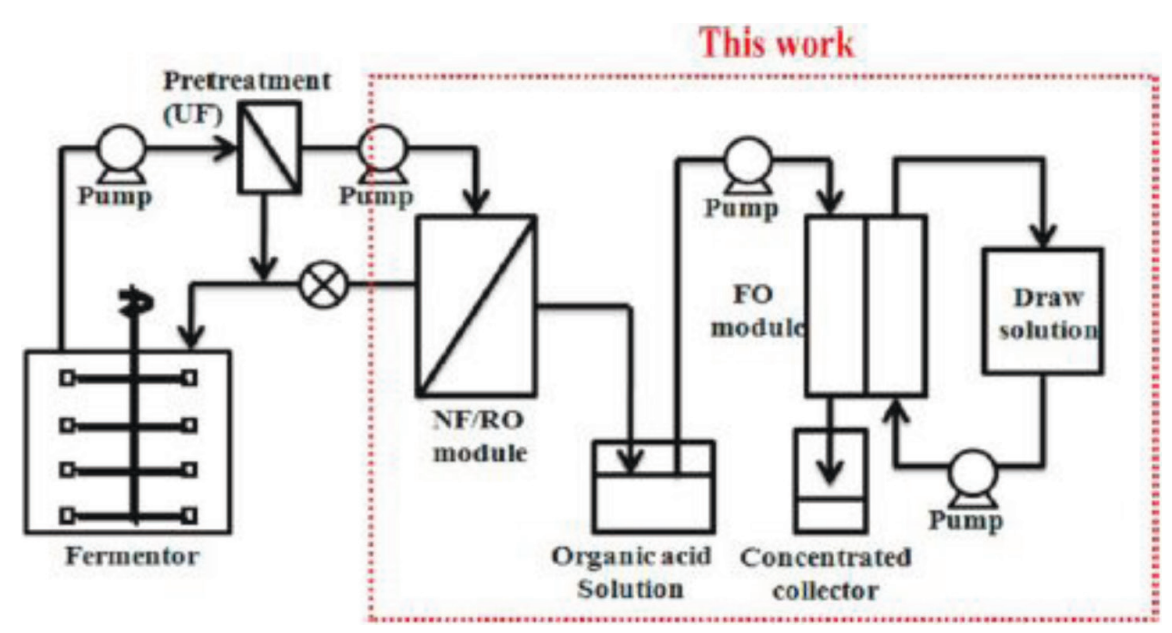

Figure 2: Schematic diagram of integrated multistage membrane system for butyric acid separation and dewatering process. ${ }^{17}$ 


\subsection{Acetic Acid}

Baruah and Hazarika ${ }^{45}$ studied the removal performance of acetic acid from dilute aqueous solution $(\leq 3 \%)$ using NF membranes prepared from $\alpha, \beta, \gamma$-cyclodextrin composite with polysulfone. The prepared membranes which are known as $\alpha-\mathrm{CD}$, $\beta-C D$, and $\gamma-C D$ membranes have asymmetric structure consisting of a dense top layer and a porous sub layer. Membrane separation performance was investigated for acetic acid aqueous solutions as a function of feed concentration, operating pressure, flow rate and operation time. Accordingly, greater permeation fluxes were observed at higher operating pressure and lower acetic acid feed concentration. Considering the operational costs involved, the researchers concluded that operating pressure of 3.5 bar was more suitable for the system though the permeation flux obtained at this pressure was slightly lower than the permeation flux at 5 bar. Of all the membranes tested, $\beta-C D$ membrane was capable of achieving $99 \%$ recovery of acetic acid from aqueous solution. The composition and physical properties of the composite $\beta$-CD membrane were $11.344 \%$ of polysulfone, $0.196 \%$ of $\mathrm{LiNO}_{3}, 1.134 \%$ of PEG, $86.946 \%$ of NMP, $12.30 \mu \mathrm{m}$ membrane thickness, 38.4 $\mathrm{nm}$ pore diameter, $0.37 \%$ of surface porosity, and $45^{\circ}$ contact angle. Additionally, the $\beta$-CD membrane also contained more interstitial cavities than $\alpha-C D$ and $\gamma-C D$ membranes.

\subsection{Fumaric Acid}

Recently, Prochaska et al. ${ }^{46}$ proposed a novel concept of fumaric acid recovery process involving an integration of NF process, bipolar electrodialysis (EDBM) and reactive extraction. A schematic diagram of three stages hybrid system is illustrated in Figure 3. In the first stage of the process, NF employing polymeric flat sheet membrane (Koch Membrane System, UK) was performed to concentrate organic acids (salt form) and remove glycerol from the fermentation broth. The authors reported that organic acids such as citric acid and cordycepic acid with molecular weights close to the MWCO of the membrane (200 Da) were $100 \%$ rejected by the membrane. Similar retention had also been observed for succinic acid $(118 \mathrm{Da})$, which is higher than that of fumaric acid. By contrast, smaller molecule such as acetic acid exhibited lower retention degree driven by solely electrostatic repulsion. The uncharged glycerol showed a much lower retention performance (less than 13\%) attributed to the absence of steric hindrance effects and electrostatic interactions.

The second stage is the bipolar electrodialysis membran (EDBM) system, mainly used for separation and concentration of fumaric acid from the NF retentate broth. Dicarboxylic acids (fumaric acid, succinic acid) were selectively separated by the 
anion-exchange membrane via three-chamber stack configuration. It was reported that fumaric acid could be concentrated and separated from the monocarboxylic acids (acetic acid, citric acid) and other impurities such as mineral salts, and unreacted glycerol. ${ }^{46}$ Nevertheless, it must be noted that $\mathrm{pH}$ plays an important role in the feasibility of EDBM since the ionic form of organic acids are only found at $\mathrm{pH}$ greater than the $\mathrm{p} K_{\mathrm{a}}$ values. In order to recover the residues of fumaric acid, reactive extraction was integrated as the third stage of the recovery process.

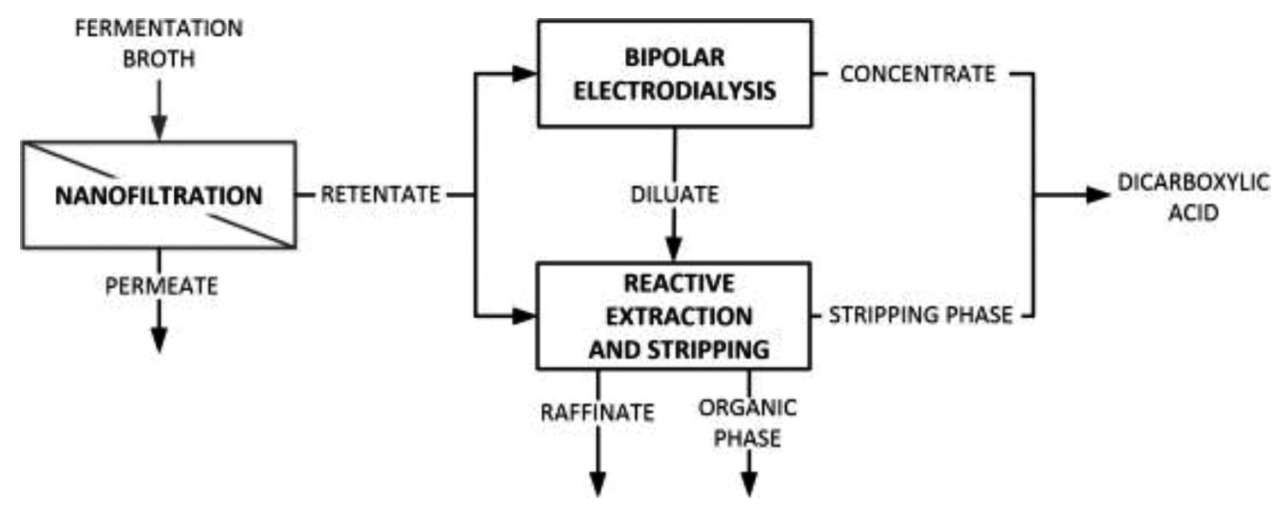

Figure 3: Schematic diagram of a novel hybrid system for the recovery of fumaric acid from fermentation broth. ${ }^{46}$

\section{Summary of Organic Acids Recovery}

It is noteworthy that many attempts have been made by integrating NF technology in the current organic acid recovery systems. Some of the key performance factors of the NF process are summarised in Table 4. Interestingly, various types of membranes have been employed in the NF process, of which composite polyamide being the majority. Polyamide membrane was widely used due to its good performance in separating multivalent ionic solute from the monovalent solutes. The selection of appropriate membrane has been the vital part of NF performance and is dependent on the composition of the fermentation broth. It can be clearly seen that for succinic acid recovery, most of the studies investigated the separation of succinic acid from other organic acids rather than the residual sugars due to the low sugar concentration in the broth. As for other organic acids such as lactic, butyric, acetic and fumaric acid recoveries, the main focus of the literature is on the separation of organic acids from sugars alcohol. 
The effects of operating parameters have also generated great interest among the researchers. As observed, the selected ranges for pressure and $\mathrm{pH}$ for NF were 5-40 bars and 3-11 values, respectively (Table 4). It was reported that the rejection of solute tends to increase with increasing operating pressure ${ }^{17}$ However, the increment of solute rejection would level off or decrease at highly applied pressure. ${ }^{47,48}$ In addition, high operating pressure also results in high permeation flux. ${ }^{45}$ Since the energy requirement for NF process is closely related to the operating pressure, the applied pressure should be minimised, at the same time maintained the rejection efficiency. ${ }^{17} \mathrm{The} \mathrm{pH}$ of feed solution strongly affects the rejection performance of NF. This is due to the surface charged groups on the active layer of NF membrane. ${ }^{17}$

Table 4: Summary of organic acids recovery from fermentation broth using NF technologies.

\begin{tabular}{|c|c|c|c|c|c|}
\hline $\begin{array}{l}\text { Organic } \\
\text { acid }\end{array}$ & $\begin{array}{l}\text { Type of NF } \\
\text { membrane }\end{array}$ & $\begin{array}{l}\text { Fermentation } \\
\text { composition }\end{array}$ & $\begin{array}{l}\text { Operating and optimum } \\
\text { parameters }\end{array}$ & $\begin{array}{l}\text { Rejection } \\
\text { performance }\end{array}$ & Ref \\
\hline \multirow[t]{4}{*}{$\begin{array}{l}\text { Succinic } \\
\text { acid }\end{array}$} & $\begin{array}{l}\text { Composite } \\
\text { polyamide (NF45, } \\
\text { NF70,ESNA1, } \\
\text { TS-4040) and } \\
\text { poly(vinyl) alcohol } \\
\text { (NTR-729HF) } \\
\text { The best membrane: } \\
\text { NF45 }\end{array}$ & $\begin{array}{l}\text { Synthetic solutions: } \\
\text { quaternary organic } \\
\text { acid salts solution } \\
\text { (succinate, formate, } \\
\text { acetate and lactate) }\end{array}$ & $\begin{array}{l}\text { Diafiltration: } \\
\text { Operation time }=36 \mathrm{~h} \\
3 \mathrm{~h} \text { continuous supplemented UP } \\
\text { water } \\
\text { Feed circulation rate }=1.5 \mathrm{~L} / \mathrm{min} \\
\text { Feed temperature }=25^{\circ} \mathrm{C} \\
\text { Fed concentration }=0.3 \mathrm{M} \text { sodium } \\
\text { succinate, } 0.1 \mathrm{M} \text { formate, acetate } \\
\text { and lactate }\end{array}$ & $\begin{array}{l}\text { Diafiltration: } \\
\text { Succinate }=78.2 \%\end{array}$ & 6 \\
\hline & $\begin{array}{l}\text { Composite } \\
\text { polyamide (ES10 } \\
\text { and NF270) }\end{array}$ & $\begin{array}{l}\text { Synthetic solutions: } \\
\text { single solute } \\
\text { solutions (formic, } \\
\text { acetic, propionic, } \\
\text { succinic and citric } \\
\text { acids) }\end{array}$ & $\begin{array}{l}\text { Cross-flow filtration: } \\
\mathrm{pH}=3-9 \\
\text { Pressure }=100-300 \mathrm{kPa} \\
\text { Feed concentration }=50-500 \mathrm{mg} / \mathrm{L} \\
\text { Optimum parameters: } \\
\mathrm{pH}=9 \\
\text { Feed concentration }=500 \mathrm{mg} / \mathrm{L} \\
\text { Pressure }=275 \mathrm{kPa}\end{array}$ & $\begin{array}{l}\text { ES } 10 \\
\text { Succinate }=80 \%-99 \% \\
\text { NF270 } \\
\text { Succinate }=90 \%-100 \%\end{array}$ & 10 \\
\hline & Ceramic & $\begin{array}{l}\text { Synthetic solution: } \\
\text { single solute } \\
\text { solutions }\end{array}$ & $\begin{array}{l}\text { Cross-flow filtration: } \\
\mathrm{pH}=3-11 \\
\text { Feed concentration }=0.29 \text { and } \\
0.58 \mathrm{~g} / \mathrm{L}\end{array}$ & - & 38 \\
\hline & $\begin{array}{l}\text { NF90, NF-DK, } \\
\text { NP030, NF270, NF- } \\
\text { DL and NP010 } \\
\text { The best } \\
\text { membranes: } \\
\text { NF270, NF-DK, } \\
\text { NF-DL }\end{array}$ & $\begin{array}{l}\text { Synthetic solution: } \\
\mathrm{NaH}_{2} \mathrm{OPO}_{4} \cdot \mathrm{H}_{2} \mathrm{O} \text {, } \\
\mathrm{K}_{2} \mathrm{HPO}_{4}, \mathrm{NaHCO}_{3} \text {, } \\
\text { sodium succinate, } \\
\text { sodium formate, } \\
\text { sodium acetate and } \\
\mathrm{NaOH}\end{array}$ & $\begin{array}{l}\text { Diafiltration: } \\
\text { Concentration of feed }=8.50 \mathrm{~g} / \mathrm{L} \\
\mathrm{NaH}_{2} \mathrm{OPO}_{4} \cdot \mathrm{H}_{2} \mathrm{O}, 15.50 \mathrm{~g} / \mathrm{L} \\
\mathrm{K}_{2} \mathrm{HPO}_{4}, 12.60 \mathrm{~g} / \mathrm{L} \mathrm{NaHCO} \mathrm{Na}_{3} \\
10 \mathrm{~g} / \mathrm{L} \text { sodium succinate, } 7.14 \mathrm{~g} / \mathrm{L} \\
\text { sodium formate and } 6.666 \mathrm{~g} / \mathrm{L} \\
\text { sodium acetate } \\
\text { Stirring speed = } 200 \mathrm{rpm} \\
\text { Operating pressure }=30 \mathrm{bar}\end{array}$ & $\begin{array}{l}\text { NF270 } \\
\text { Succinate }=88.9 \% \\
\text { NF-DK } \\
\text { Succinate }=86.6 \% \\
\text { NF-DL } \\
\text { Succinate }=79.0 \%\end{array}$ & 30 \\
\hline
\end{tabular}


Table 4: (Continued)

\begin{tabular}{|c|c|c|c|c|c|}
\hline $\begin{array}{l}\text { Organic } \\
\text { acid }\end{array}$ & $\begin{array}{l}\text { Type of NF } \\
\text { membrane }\end{array}$ & $\begin{array}{l}\text { Fermentation } \\
\text { composition }\end{array}$ & $\begin{array}{l}\text { Operating and optimum } \\
\text { parameters }\end{array}$ & $\begin{array}{l}\text { Rejection } \\
\text { performance }\end{array}$ & Ref \\
\hline \multirow[t]{4}{*}{$\begin{array}{l}\text { Lactic } \\
\text { acid }\end{array}$} & Desal 5 DK & $\begin{array}{l}\text { Industrial fluids: } \\
\text { Clarified } \\
\text { fermentation broth } \\
\text { (MF) and clarified, } \\
\text { concentrated } \\
\text { and converted } \\
\text { fermentation broth } \\
\text { (MF-CED-BED) }\end{array}$ & $\begin{array}{l}\text { Cross-flow filtration: } \\
\text { Transmembrane pressure }=2-20 \\
\text { bar } \\
\text { MF feed composition }=4 \mathrm{mM} \\
\text { lactic acid and } 0.86 \mathrm{M} \text { lactate } \\
\text { MF-CED-BED feed composition } \\
=1.57 \mathrm{M} \text { lactic acid and } 40 \mathrm{mM} \\
\text { lactate } \\
\text { Optimum parameters: } \\
20 \text { bar } \\
\text { Cross-flow velocity }=1.3 \mathrm{~m} / \mathrm{s}\end{array}$ & $\begin{array}{l}\text { MF feed }=18 \% \text { lactate } \\
\text { MF-CED-BED feed = } \\
15 \% \text { lactic acid }\end{array}$ & 40 \\
\hline & $\begin{array}{l}\text { Composite } \\
\text { polyamide (NF2, } \\
\text { NF3, NF20) } \\
\text { The best membrane: } \\
\text { NF3 }\end{array}$ & $\begin{array}{l}\text { Actual broth: lactic } \\
\text { acid, residual } \\
\text { sucrose, glucose } \\
\text { and fructose }\end{array}$ & $\begin{array}{l}\text { Cross-flow filtration: } \\
\text { Transmembrane pressure }=5-15 \\
\text { bars } \\
\text { Cross flow velocity }=1.77-2.48 \\
\mathrm{~m} / \mathrm{s} \\
\text { Optimum parameters: } \\
\text { pH }=5.5 \\
\text { Transmembrane pressure }=13 \text { bar } \\
\text { Cross flow velocity }=2.48 \mathrm{~m} / \mathrm{s}\end{array}$ & Lactic acid $=68 \%$ & 41 \\
\hline & $\begin{array}{l}\text { Polyamide (Spiral } \\
\text { wound; DK2540C, } \\
\text { Tubular; AFC 80) } \\
\text { The best membrane: } \\
\text { DK2540C }\end{array}$ & $\begin{array}{l}\text { Actual clarified } \\
\text { broth: mineral, } \\
\text { lactic acid, } \\
\text { chloride }\end{array}$ & $\begin{array}{l}\text { Cross-flow filtration: } \\
\text { Transmembrane pressure: } 10-40 \\
\text { bar } \\
\text { pH: } 2.7-6 \\
\text { Cross flow velocity: } 1.2 \text { and } 2.7 \\
\text { m/s } \\
\text { Optimum parameters: } \\
\text { Transmembrane pressure }=30 \text { bar } \\
\text { pH }=6 \\
\text { Cross flow velocity }=\text { no effect } \\
\text { on rejection performance of } \\
\text { membrane }\end{array}$ & Lactate $=91 \%$ & 39 \\
\hline & $\begin{array}{l}\text { Aromatic polyamide } \\
\text { (NF-200B) }\end{array}$ & $\begin{array}{l}\text { Synthetic solutions: } \\
\text { lactate, } \mathrm{NaCl}\end{array}$ & $\begin{array}{l}\text { pH: } 3-10 \\
\text { Temperature: } 20^{\circ} \mathrm{C}-40^{\circ} \mathrm{C} \\
\text { Feed concentration: } 2 \%(\mathrm{w} / \mathrm{v}) \\
\text { lactate with } 0-17 \%(\mathrm{w} / \mathrm{v}) \mathrm{NaCl} \\
\text { concentration } \\
\text { Optimum parameters: } \\
\mathrm{pH}=7-8 \text { depending on } \\
\text { concentration of } \mathrm{NaCl} \\
\text { Temperature }=20^{\circ} \mathrm{C} \\
\text { Transmembrane pressure }=10 \mathrm{bar}\end{array}$ & $\begin{array}{l}\text { Lactate without salt = } \\
93 \%(\mathrm{pH} 7) \\
\text { Lactate with } 4 \%(\mathrm{w} / \mathrm{v}) \\
\mathrm{NaCl}=85 \%(\mathrm{pH} 7-9) \\
\text { Lactate with } 9 \%(\mathrm{w} / \mathrm{v}) \\
\mathrm{NaCl}=86 \%(\mathrm{pH} 7) \\
\text { Lactate with } 17 \% \\
(\mathrm{w} / \mathrm{v}) \mathrm{NaCl}=53 \% \\
(\mathrm{pH} 10)\end{array}$ & 49 \\
\hline
\end{tabular}


Table 4: (Continued)

\begin{tabular}{|c|c|c|c|c|c|}
\hline $\begin{array}{l}\text { Organic } \\
\text { acid }\end{array}$ & $\begin{array}{l}\text { Type of NF } \\
\text { membrane }\end{array}$ & $\begin{array}{l}\text { Fermentation } \\
\text { composition }\end{array}$ & $\begin{array}{l}\text { Operating and optimum } \\
\text { parameters }\end{array}$ & $\begin{array}{l}\text { Rejection } \\
\text { performance }\end{array}$ & Ref \\
\hline $\begin{array}{l}\text { Butyric } \\
\text { acid }\end{array}$ & Polyamide (HL) & $\begin{array}{l}\text { Single solute NF/RO } \\
\text { feed: ammonium } \\
\text { sulfate }(1000 \mathrm{ppm}) \text {, } \\
\text { potassium phosphate } \\
(1000 \mathrm{ppm}), \text { glucose } \\
(10000 \mathrm{ppm}) \text {, yeast } \\
\text { extract }(1000 \mathrm{ppm}) \text {, } \\
\text { and butyric acid } \\
(1000 \mathrm{ppm}) .\end{array}$ & $\begin{array}{l}\text { Dead end filtration: } \\
\text { Pressure }=5-15 \text { bar } \\
\mathrm{pH}=3,6,9 . \\
\text { Temperature: } 25^{\circ} \mathrm{C} \\
\text { Stirring speed }=800 \mathrm{rpm} \\
\text { Optimum parameters: } \\
\text { Pressure = no effect on rejection } \\
\text { performance of membrane } \\
\mathrm{pH}=9\end{array}$ & Butyric $=>90 \%$ & 17 \\
\hline $\begin{array}{l}\text { Acetic } \\
\text { acid }\end{array}$ & $\begin{array}{l}\alpha-C D, \beta-C D \text {, and } \\
\gamma-C D \text { membranes } \\
\text { The best membrane: } \\
\beta-C D \text { membrane }\end{array}$ & $\begin{array}{l}\text { Synthetic solutions: } \\
\text { acetic acid }\end{array}$ & $\begin{array}{l}\text { Dead end filtation: } \\
\text { Feed concentration: } 0.174 \mathrm{~mol} / \mathrm{L}(1 \\
\mathrm{wt} \%) \text { to } 1.223 \mathrm{~mol} / \mathrm{L}(7 \mathrm{wt} \%) \\
\text { Pressure }=1-5 \mathrm{bar} \\
\text { Flow Rate }=2-18 \mathrm{~L} / \mathrm{h} \\
\text { Operation time }=1-15 \text { months } \\
\text { Optimum parameters: } \\
\text { Feed concentration }=<0.611 \\
\text { mol } / \mathrm{L}(3.5 \%) \\
\text { Pressure }=3.5 \text { bar } \\
\text { Flow rate of feed stock }=\text { no } \\
\text { significant effect on rejection } \\
\text { performance of membrane } \\
\text { Operation time }=3-4 \text { months }\end{array}$ & Acetic acid $=99 \%$ & 45 \\
\hline \multirow[t]{2}{*}{$\begin{array}{l}\text { Fumaric } \\
\text { acid }\end{array}$} & $\begin{array}{l}\text { Polymeric } \\
\text { membrane (Koch } \\
\text { Membrane System, } \\
\text { UK) }\end{array}$ & $\begin{array}{l}\text { Actual broth: } \\
\text { glycerol, fumaric, } \\
\text { acetic, succinic, } \\
\text { cordycepic, and } \\
\text { citric acids }\end{array}$ & $\begin{array}{l}\text { Cross-flow filtration: } \\
\text { Transmembrane pressure }=0.8-1.4 \\
\mathrm{MPa} \\
\mathrm{pH}=6.4 \\
\text { Retentate circulation flow rate }= \\
160 \mathrm{~L} / \mathrm{h}(0.7 \mathrm{~m} / \mathrm{s}) \\
\text { Temperature }=25^{\circ} \mathrm{C} \\
\text { Fumaric acid concentration }= \\
1.99 \mathrm{~g} / \mathrm{L} \\
\text { Optimum Parameters: } \\
\text { Transmembrane pressure }=0.8 \\
\mathrm{MPa}\end{array}$ & Fumaric acid $=95.2 \%$ & 46 \\
\hline & $\begin{array}{l}\text { Tubular ceramic } \\
\text { nanochannel } \\
\text { membrane (Inopor) }\end{array}$ & $\begin{array}{l}\text { Actual Broth: } \\
\text { Fumaric, succinic, } \\
\text { citric acids }\end{array}$ & $\begin{array}{l}\text { Cross-flow filtration: } \\
\text { Transmembrane pressure }=0.4- \\
1.4 \mathrm{MPa} \\
\mathrm{pH}=3-11 \\
\text { Feed concentration }=2 \mathrm{~g} / \mathrm{L} \text { fumaric } \\
\text { acid, } 0.05 \mathrm{~g} / \mathrm{L} \text { succinic acid and } \\
0.2 \text { citric acid } \\
\text { Optimum Parameters: } \\
\text { Transmembrane pressure }= \\
1.4 \mathrm{MPa} \\
\mathrm{pH}=6\end{array}$ & Fumaric acid $=80 \%$ & 50 \\
\hline
\end{tabular}


When the feed solution contained organic acids with MW close to the MWCO of the NF membrane, the rejection of the organic acids by the membrane is mainly governed by the size exclusion mechanism rather than Donnan exclusion, hence, organic acids with smaller molecular sizes show greater permeation or lower rejection. However, at high $\mathrm{pH}$ (isoelectric point), the zeta potential of the membrane surface becomes negative and the organic acids are usually appearing in ionic anions. As a consequence, the rejection of ionic species with MW lower than the MWCO of the membrane is driven by solely electrostatic repulsion. ${ }^{17,46}$ The feed solution concentration (fermentation broth) can be varied depending on the fermentation methods. High feed concentration results in low permeation flux of NF process. ${ }^{45}$

Overall, several research gaps in the current reported literature deserve more attention in the future. Although the major improvement and development of commercial NF membrane in recent years has seen great potential for NF application in organic acids recovery, more efforts are needed to validate the rejection and selectivity performances of these membranes in the particular application. Despite the performance studies under wide range of operating parameters, the observed organic acids recovery remains a challenge in high broth concentration. Additionally, the use of actual fermentation broth for validating the separation performances would be of highly desired.

\section{CONCLUSION}

The use of biomass feedstock as raw materials for producing highly valuable organic acids is driven by a reduction of fossil raw materials and movement towards green technology. Nevertheless, the downstream recovery of organic acids from fermentation broth has been an on-going challenge due to the presence of multiple by-products in the broth, low organic acids concentration, the production of organic acids in salt form, and high energy required to remove excess water from the recovered organic acids. Accordingly, efficient recovery approaches and technologies must be found with regard to yield, purity, and energy consumption. One of the promising recovery technologies is the membrane-based process which offers synergetic improvement on the overall process from the combination of the types of membrane and process modules. As a mature technology, membranebased NF appears very attractive, which is attributed to its separation mechanism and membrane properties. The retention of NF membrane is mainly governed by Donnan exclusion and size exclusion mechanisms. In recent years, the integration 
of NF with other separation technologies such as FO, ED, RO or EDBM have been proposed for targeting high productivity and purity of organic acids. Integrated NF technologies coupled with upstream fermentation, in-situ organic acids recovery and biorefining strategy deserve more attentions in the future.

\section{ACKNOWLEDGEMENTS}

The authors wish to gratefully acknowledge the financial support for this work provided by the LRGS/2013/UKM-UKM/PT/03 and LRGS/2013/UKM-UKM/ PT/01 grants from the Ministry of Higher Education Malaysia.

\section{REFERENCES}

1. Schlosser, S. \& Blahusial, M. (2011). Biorefinery for production of chemicals, energy and fuels. Electroen., 4(2), 8-16.

2. Zeikus, J. G., Jain, M. K. \& Elankovan, P. (1999). Biotechnology of succinic acid production and markets for derived industrial products. Appl. Microbiol. Biotechnol., 51, 545-552, https://doi.org/10.1007/s002530051431.

3. Agarwal, L., Isar, J. \& Saxena, R. (2005). Rapid screening procedures for identification of succinic acid producers. J. Biochem. Biophys., 63, 24-32, https://dx.doi.org/10.1016/j.jbbm.2005.01.002.

4. Li, Q. et al. (2010). One step recovery of succinic acid from fermentation broths by crystallization. Sep. Purif. Technol., 72, 294-300, https://dx.doi. org/10.1016/j.seppur.2010.02.021.

5. Caixia, W. et al. (2014). Novel membrane-based biotechnological alternative process for succinic acid production and chemical synthesis of bio-based poly (butylene succinate). Biores. Technol., 156, 6-13, http://dx.doi.org/ 10.1016/j.biortech.2013.12.043.

6. Kang, S. H. \& Chang, Y. K. (2005). Removal of organic acid salts from simulated fermentation broth containing succinate by nanofiltration. J. Membr. Sci., 246, 49-57, http://dx.doi.org/10.1016/j.memsci.2004.08.014.

7. Song, H. \& Lee, S. Y. (2006). Production of succinic acid by bacterial fermentation. Enz. Microb. Technol., 39, 352-361, http://dx.doi.org/ 10.1016/j.enzmictec.2005.11.043.

8. Song, H. et al. (2008). Modelling of batch fermentation kinetics for succinic acid production by Mannheimia succiniciproducens. Biochem. Eng. J., 40, 107-115, http://dx.doi.org/10.1016/j.bej.2007.11.021. 
9. Saxena, A. et al. (2009). Membrane-based techniques for the separation and purification of proteins: An overview. Adv. Colloid Interf. Sci., 145, 1-22, https://dx.doi.org/10.1016/j.cis.2008.07.004.

10. Choi, J.-H., Fukushi, K. \& Yamamoto, K. (2008). A study on the removal of organic acids from wastewaters using nanofiltration membranes. Sep. Purif. Technol., 59, 17-25.

11. Chimirri, F. et al. (2010). Succinic acid and its derivatives: Fermentative production using sustainable industrial agro-food by-products and its applications in the food industry. Ital. J. Food Sci., 22, 119-125.

12. Sener, A. et al. (1997). Synergistic insulinotropic action of succinate, acetate, and glucose esters in islets from normal and diabetic rats. Endocrine, 7, 151155.

13. Willke, T. H. \& Vorlop, K.-D. (2004). Industrial bioconversion of renewable resources as an alternative to conventional chemistry. App. Microbiol. Biotechnol., 66, 42-131, https://dx.doi.org/10.1007/s00253-004-1733-0.

14. Datta, R. \& Henry, M. (2006). Lactic acid: Recent advances in products, processes and technologies. J. Chem. Technol. Biotechnol., 81, 1119-1129, https://doi.org/10.1002/jctb.1486.

15. Zhang, C. et al. (2009). Current progress on butyric acid production by fermentation. Curr. Microbiol., 59, 656-663, https://dx.doi.org/10.1007/ s00284-009-9491-y.

16. Zigova, J. \& Sturdik, E. (2000). Advances in biotechnological production of butyric acid. J. Ind. Microbiol. Biotechnol, 24, 153-160.

17. Cho, Y. H., Lee, H. D. \& Park, H. B. (2012). Integrated membrane processes for separation and purification of organic acid from a biomass fermentation process. Ind. Eng. Chem. Res., 51, 10207-10219, https://doi.org/10.1021/ ie301023r.

18. Zigova, J., Ernest, S. S. \& Vandak, D. S. (1999). Butyric acid production by Clostridium butyricum with integrated extraction and pertraction. Process. Biochem., 34, 835-843, http://dx.doi.org/10.1016/S0032-9592(99)00007-2.

19. Blank-Porat, D. et al. (2007). The anticancer prodrugs of butyric acid AN-7 and AN-9, possess antiangiogenic properties. Cancer Lett., 256, 39-48, https://dx.doi.org/10.1016/j.canlet.2007.05.011.

20. Yoneda, N. et al. (2001). Recent advances in processes and catalysts for the production of acetic acid. App. Catal. A: Gen., 221, 253-265, https://doi. org/10.1016/s0926-860x(01)00800-6.

21. Baker, R. W. (2004). Membrane technology and application. New York: John Wiley \& Sons.

22. van Reis, R. \& Zydney, A. (2007). Bioprocess membrane technology. J. Membr. Sci., 297, 16-50, https://doi.org/10.1016/j.memsci.2007.02.045. 
23. Mohammad, A. W. et al. (2015). Nanofiltration membranes review: Recent advances and future prospects. Desalin., 356, 226-254, http://dx.doi. org/10.1016/j.desal.2014.10.043.

24. Bruggen, B. V. d. et al. (2003). A review of pressure-driven membrane processes in wastewater treatment and drinking water production. Environ. Progress, 22(1), 46-56, https://doi.org/10.1002/ep.670220116.

25. Yaroshchuk, A. E. (1998). Rejection mechanism of NF membranes. Membr. Tech., (100), 9-12, http://dx.doi.org/10.1016/S0958-2118(00)87465-0.

26. Oatley, D. L. et al. (2012). Review of the dielectric properties of nanofiltrationmembranes and verification of the single oriented layer approximation. Adv. Colloid Interf., 173, 1-11, https://dx.doi.org/10.1016/j. cis.2012.02.001.

27. Donnan, F. G. (1995). Theory of membrane equilibria and membrane potentials in the presence of non-dialysing electrolytes. A contribution to physical-chemical physiology. J. Membr. Sci., 100, 45-55, http://dx.doi. org/10.1016/0376-7388(94)00297-C.

28. Rautenbach, R. \& Groschl, A. (1990). Separation potential of nanofiltration membranes. Desalin., 77, 73-84, http://dx.doi.org/10.1016/0011-9164(90) 85021-2.

29. Ernst, M. et al. (2000). Zeta-potential and rejection rates of a polyethersulfone nanofiltration membrane in single salt solutions. J. Membr. Sci., 165, 251259, http://dx.doi.org/10.1016/S0376-7388(99)00238-0.

30. Sosa, P. A., Roca, C. \& Velizarov, S. (2016). Membrane assisted recovery and purification of bio-based succinic acid for improved process sustainability. $J$. Membr. Sci., 501, 236-247, http://dx.doi.org/10.1016/j.memsci.2015.12.018.

31. Schaep, J. \& Vandecasteele, C. (2001). Evaluating the charge of nanofiltration membranes. J. Membr. Sci., 188, 129-136.

32. Peeters, J. M. M. et al. (1998). Retention measurements of nanofiltration membranes with electrolyte solutions. J. Membr. Sci., 145, 199-209, http://dx.doi.org/10.1016/S0376-7388(98)00079-9.

33. Bowen, W. R. \& Mukhtar, H. (1996). Characterization and prediction of separation performance of nanofiltration membranes. J. Membr. Sci., 112, 263, http://dx.doi.org/10.1016/0376-7388(95)00302-9.

34. Deen, W. M. (1987). Hindered transport of largne molecules in liquid-filled pores. AIChE J., 33, 1409-1425, https://doi.org/10.1002/aic.690330902.

35. Paugam, L. et al. (2004). Mechanism of nitrate ions transfer in nanofiltration depending on pressure, $\mathrm{pH}$, concentration and medium composition. J. Membr. Sci., 231, 37-46.

36. Ballet, G. T., Hafiane, A. \& Dhahbi, M. (2007). Influence of operating conditions on the retention of phosphate in water by nanofiltration. J. Membr. Sci., 290, 164-172, https://dx.doi.org/10.1016/j.memsci.2006.12.046. 
37. Van der Burggen, B. et al. (1999). Influence of molecular size, polarity and change on the retention of organic molecules by nanofiltration. J. Membr. Sci., 156, 29-41.

38. Staszak, K. et al. (2013). Application of nanofiltration in the process of the separation of model fermentation broth components. Polish J. Chem. Technol., 15(4), 1-4, https://doi.org/10.2478/pjct-2013-0058.

39. Gonzalez, M. I. et al. (2008). Lactic acid recovery from whey ultrafiltration fermentation broths and artificials solutions by nanofiltration. Desalin., 228, 84-96.

40. Bouchoux, A., Balmann, H. R. \& Lutin, F. (2006). Investigation of nanofiltration as a purification step for lactic acid production processes based on conventional and bipolar electrodialysis operations. Sep. Pur. Technol., 52, 266-273, http://dx.doi.org/10.1016/j.seppur.2006.05.011.

41. Sikder, J. et al. (2012). Purification of lactic acid from microfiltrate fermentation broth by cross-flow nanofiltration. Biochem. Eng. J., 69, 130137.

42. Polom, E. (2013). The fouling of zirconium(IV) hydrous oxide-polyacrylate dynamicallyformedmembranesduringthenanofiltrationoflacticacidsolutions. Membr., 3, 415-442, https://dx.doi.org/10.3390\%2Fmembranes3040415.

43. Bouchoux, A., Balmann, H. R. \& Lutin, F. (2006). Investigation of nanofiltration as a purification step for lactic acid production processes based on conventional and bipolar electrodialysis operations. Sep. Purif. Technol., 52, 226-273, http://dx.doi.org/10.1016/j.seppur.2006.05.011.

44. Duke, M. C. et al. (2008). Lactic acid enrichment with inorganic nanofiltration and molecular sieving membranes by pervaporation. Food Bioprod. Process., 86(4), 290-295, http://dx.doi.org/10.1016/j.fbp.2008.01.005.

45. Baruah, K. \& Hazarika, S. (2014). Separation of acetic acid from dilute aqueous solution by nanofiltration membrane. J. Appl. Polym. Sci., 131, 40537, https://doi.org/10.1002/app.40537.

46. Prochaska, K. et al. (2014). Nanofiltration, bipolar electrodialysis and reactive extraction hybrid system for separation of fumaric acid from fermentation broth. Bioresour. Technol., 167, 219-225, https://dx.doi.org/10.1016/j. biortech.2014.06.010.

47. Lubsungneon, J. et al. (2014). Nanofiltration coupled with vapor permeatingassisted esterification as an effective purification step for fermentation-derived succinic acid. J Membr. Sci., 459, 132-142, http://dx.doi.org/10.1016/j. memsci.2014.02.006.

48. Pontalier, P. Y., Ismail, A. \& Ghoul, M. (1997). Mechanisms for the selective rejection of solutes in nanofiltration membranes. Sep. Purif. Technol, 12, 175-181, http://dx.doi.org/10.1016/S1383-5866(97)00047-6. 
49. Freger, V., Arnot, T. C. \& Howell, J. A. (2000). Separation of concentrated organic/inorganic salt mixtures by nanofiltration. J. Membr. Sci., 178, 185193, http://dx.doi.org/10.1016/S0376-7388(00)00516-0.

50. Wozniak, M. J. \& Prochaska, K. (2014). Fumaric acid separation from fermentation broth using nanofiltration (NF) and bipolar electrodialysis (EDBM). Sep. Purif. Technol., 125, 179-186. 
